\title{
Faktor Lingkungan dan Genetik penyebab Kejadian Overweight pada Balita Usia 3-5 Tahun di Kota Kediri
}

\author{
Umianita Risca Wulandari ${ }^{1}$, Alfadefi Khalifatunnisak ${ }^{1}$ \\ ${ }^{1}$ Institut Ilmu Kesehatan Bhakti Wiyata Kediri - Jln. KH Wachid Hasyim 65 Kediri \\ Corresponding author: Umianita Risca Wulandari (umianita03@gmail.com)
}

Received 16 August 2019; Accepted 20 August 2019; Published 5 September 2019

\begin{abstract}
ABSTRAK
Abstrak : Overweight adalah suatu keadaan dimana berat badan di atas kondisi normal. Hal tersebut dapat terjadi karena jumlah nutrisi yang dikonsumsi lebih banyak dibandikan energi yang dikeluarkan. Jika sejak usia anak sudah mengalami obesitas maka di usia tua akan rentan mengalami gangguan kesehatan yang berhubungan dengan penyakit metabolik dan degenartif. Penelitian ini bertujuan untuk mengetahui hubungan faktor lingkungan dan genetik terhadap kejadian overweight pada Balita usia 3-5 tahun di Kota Kediri. Metode yang digunakan adalah analitik observasional. Penelitian dilaksanakan di Kota Kediri pada bulan Mei 2018 dengan jumlah sampel sebanyak 100 subjek dengan menggunakan teknik fixed exprosure sampling. Analisa data yang digunakan adalah uji chi square. Hasil penelitian menujukkan bahwa Indeks Masa Tubuh ibu, pemberian Makanan Pendamping ASI dini dan pola asupan nutrisi berhubungan dengan kejadian overweight pada balita usia 3- 5 tahun dan secara statistik signifikan dengan nilai $\mathrm{p}<0,05$.
\end{abstract}

Kata Kunci: Faktor Lingkungan, Genetik, Overweight, Balita

Copyright @ 2019 Institut Ilmu Kesehatan STRADA Indonesia All rights reserved.

This is an open-acces article distributed under the terms of the Creative Commons Attribution-ShareAlike 4.0 International License.

\section{PENDAHULUAN}

Kegemukan dan obesitas merupakan masalah kesehatan yang disebabkan karena asupan energi lebih tinggi dibandingkan energi yang terpakai. Kegemukan yang terjadi di Indonesia saat ini dapat terjadi pada semua kelompok umur dan berbagai status sosial ekonomi. Kasus kegemukan yang terjadi pada masa balita dapat menyebabkan gangguan kesehatan yaitu penyakit metabolik maupun degeneratif yang dapat menurunkan kualitas hidup di masa mendatang (Kemenkes RI, 2012).

Berdasarkan data dari World Health Organization ( 2018) menyebutkan bahwa sejumlah $18 \%$ anak di dunia mengalami kegemukan dan obesitas. Indonesia merupakan negara dengan urutan ke 17 yang masih mempunyai permasalahan gizi salah satunya balita dengan gizi gemuk (Depkes RI, 2017). Berdasarkan hasil Riskesdas (2018) menunjukkan bahwa balita dengan status gizi gemuk sebanyak $8 \%$ dan masih terdapat 13 Propinsi di Indonesia yang mempunyai jumlah balita dengan gizi gemuk di atas proporsi nasional, salah satunya yaitu Propinsi Jawa Timur.

Jumlah balita dengan status gizi gemuk di Kota Kediri hampir sebesar $8 \%$ dan sudah mengalami penurunan dibandingkan tahun 2013 yaitu hampir 15\%. Meskipun jumlah tersebut di bawah angka Jawa Timur, akan tetapi jumlah tersebut tergolong cukup besar (Riskesdas, 2018). Terdapat beberapa faktor yang menjadi penyebab obesitas seperti ketidakseimbangan pola makan, perilaku makan, aktivitas fisik, riwayat 
pemberian Air Susu Ibu maupun genetik. Oleh karena itu untuk mencegah peningkatan jumlah balita dengan gizi gemuk diperlukan upaya mulai dari keluarga untuk berperilaku hidup sehat.

\section{METODE}

Penelitian ini menggunakan metode analitik observasional.. Penelitian dilaksanakan di wilayah Kota Kediri pada bulan Mei tahun 2018. Populasi dalam penelitian ini adalah seluruh balita yang berusia 3-5 yang berada di Kecamatan Kediri Kota. Jumlah sampel dalam penelitian ini sebanyak 100 subjek. Teknik sampling yang digunakan yaitu fixed exposure sampling yaitu sampel diambil dari status paparan subjek.

Variabel yang digunakan pada penelitian ini adalah variabel dependen dan independen. Yang menjadi variabel dependen adalah kejadian overweight, sedangkan yang menjadi variabel independen adalah pemberian makanan pendamping ASI dini, asupan nutrisi, dan Indeks Masa Tubuh Ibu. Variabel pemberian makanan pendamping ASI dini adalah bayi yang diberikan makanan pendamping selain ASI pada usia $<6$ bulan. Variabel asupan nutrisi adalah jumlah asupan nutrisi yang dikonsumsi setiap hari sesuai dengan nilai angka kecukupan gizi yang dikategorikan mnejadi sesuai angka kecukupan gizi dan lebih dari nilai angka kecukupan gizi.. Variabel indeks masa tubuh ibu adalah status gizi ibu yang dihitung dengan membandingkan antara berat badan dengan tinggi badan kuadarat yang dikategorikan menjadi kurus jika IMT < 17, normal jika IMT 17 - 23, kegemukan jika IMT 23 - 27 dan obesitas jila IMT > 27.

\section{HASIL}

Tabel 1. Karakteristik Responden

\begin{tabular}{llcc}
\hline Variabel & Kriteria & $\mathrm{n}$ & $\%$ \\
\hline Status Gizi Balita & Kurus & 4 & 4 \\
& Baik & 71 & 71 \\
IMT Ibu & Overweight & 25 & 25 \\
& BB Ideal & 44 & 44 \\
MP ASI Dini & BB Gemuk & 39 & 39 \\
& Obesitas & 17 & 17 \\
Asupan Nutrisi & Ya & 74 & 74 \\
& Tidak & 26 & 26 \\
& Sesuai AKG & 60 & 60 \\
& Lebih dari AKG & 40 & 40
\end{tabular}

Sumber : Data Primer, 2018

Berdasarkan tabel 1 diatas menunjukkan bahwa status gizi balita sebagian besar ( $71 \%$ ) yaitu sebanyak 71 orang mempunyai status gizi yang baik dan sebagian kecil ( $25 \%$ ) yaitu sebanyak 25 orang mempunyai status gizi gemuk. Status indeks masa tubuh ibu hampir setengahnya (44\%) yaitu sebayak 44 orang mempunyai berat badan yang ideal, sebanyak $39 \%$ yaitu 39 orang mempunyai berat badang gemuk dan sebagian kecil (17\%) yaitu sebanyak 17 orang mempunyai status obesitas. Sedangkan sebanyak 74 orang (74\%) memberikan Makanan Pendamping ASI dini kepada bayinya dan hanya 26 orang (26\%) yang memberikan ASI Ekslusif. Pola asupan nutrisi balita yang sesuai dengan Angka Kecukupan Gizi sebanyak 60\% ( 60 orang) dan balita yang asupan nutrisinya lebih dari Angka Kecukupan Gizi sebanyak $40 \%$ (40 orang). 
Tabel 2. Hubungan antar variabel dengan kejadian overweight pada balita usia $3-5$ tahun

\begin{tabular}{|c|c|c|c|c|c|c|c|}
\hline \multirow{3}{*}{ Variabel } & \multicolumn{6}{|c|}{ Kejadian Overweight pada Balita } & \multirow{3}{*}{$\mathrm{p}$} \\
\hline & \multicolumn{2}{|c|}{ Kurus } & \multicolumn{2}{|c|}{ Baik } & \multicolumn{2}{|c|}{ Overweight } & \\
\hline & $\mathrm{n}$ & $\%$ & $\mathrm{n}$ & $\%$ & $\mathrm{n}$ & $\%$ & \\
\hline \multicolumn{8}{|l|}{ IMT Ibu } \\
\hline 1. BB Ideal & 2 & 0,02 & 33 & 0,33 & 9 & 0,09 & 0,002 \\
\hline 2. BB Gemuk & 2 & 0,02 & 27 & 0,27 & 10 & 0,10 & \\
\hline 3. Obesitas & 0 & 0 & 11 & 0,11 & 6 & 0,06 & \\
\hline \multicolumn{8}{|l|}{ MP Asi Dini } \\
\hline 1. Diberikan & 2 & 0,02 & 52 & 0,52 & 20 & 0,20 & 0,000 \\
\hline 2. Tidak Diberikan & 2 & 0,02 & 19 & 0,19 & 5 & 0,05 & \\
\hline \multicolumn{8}{|l|}{ Pola Asupan Nutrisi } \\
\hline 1. Sesuai AKG & 3 & 0,03 & 50 & 0,50 & 7 & 0,07 & 0.046 \\
\hline 2. Lebih dari $\mathrm{AKG}$ & 1 & 0,01 & 21 & 0,21 & 18 & 0,18 & \\
\hline
\end{tabular}

Sumber : Data Primer, 2018

Hasil analisis Chi-Square menunjukkan bahwa terdapat hubungan antara Indeks Masa Tubuh Ibu $(p=0,002)$, pemberian Makanan Pendamping ASI Dini $(p=0,000)$ dan Pola Asupan Nutrisi $(p=0,046)$ terhadap kejadian overweihgt pada balita usia $3-5$ tahun dengan nilai $\mathrm{p}$ value $<0.05$.

\section{PEMBAHASAN}

\section{Indeks Masa Tubuh Ibu}

Pada penelitian ini menunjukkan bahwa berdasarkan Indeks Masa Tubuh masih banyak ibu balita yang mempunyai status gizi gemuk dan obesitas. Indeks Masa Tubuh/ IMT dapat mewakili faktor genetik yang menyebabkan obesitas pada anak. Berdasarkan hasil penelitian menujukkan bahwa ibu yang gemuk dan obesitas sebagian besar mempunyai anak dengan status gizi overweight/ gemuk. Menurut Mariam \& Larasati (2016) mengemukakan bahwa anak akan mempunyai peluang gemuk dan obesitas sebesar $80 \%$ jika kedua orang tua obesitas, $40 \%$ berpeluang memiliki anak yang obesitas jika salah satu orang tua mengalami obesitas dan meskipun kedua orang tua tidak ada yang obesitas anak tetap mempunyai peluang untuk mengalami obesitas sebesar 14\%. Hal yang sama juga terjadi pada penelitian yang dilakukan oleh Swanton, S et al (2017) yang menyebutkan bahwa ibu yang mengalami obesitas akan menjadi faktor pencetus obesitas bagi anak yang dilahirkan, terutama anak perempuan.

\section{MP ASI Dini}

Berdasarkan hasil penelitian menunjukkan bahwa sebagian besar balita usia 3 - 5 tahun telah diberikan Makanan Pendamping ASI dini. Jenis MP ASI Dini yang diberikan sebagian besar adalah susu formula dan makanan padat yang tidak sesuai dengan umur. Hal tersebut sangat bertentangan dengan rekomendasi UNICEF dan WHO yang menganjurkan pemberian Air Susu Ibu sampai bayi berusia 6 bulan ( Kemenkes RI, 2014). Ketika bayi sebelum usia 6 bulan telah diberikan makanan tambahan yang tidak sesuai dengan kebutuhan tubuhnya, yang dalam hal ini porsi makan lebih besar dari kebutuhannya maka bayi akan terbiasa dengan porsi makan yang banyak, hal inilah yang dapat memicu terjadinya kegemukan atau obesitas pada anak. Penelitian yang dilakukan oleh Utami \& Wijayanti (2017) juga menyebutkan bahwa Balita yang mengkonsumsi susu formula sebelum usia 6 bulan berisiko 6.19 kali lebih besar untuk mengalami kegemukan. Hal tersebut disebabkan karena tingginya kandungan protein pada dapat memicu peningkatan sekresi hormone insulin yang selanjutnya berdampak pada penambahan jumlah adiposa di tubuh anak. 


\section{Pola Asupan Nutrisi}

Berdasarkan hasil penelitian menunjukkan bahwa balita yang mempunyai status gizi overweight mempunyai pola asupan nutrisi diatas nilai Angka Kecukupan Gizi (AKG). Ketidakseimbangan pola konsumsi nutrisi dapat menyebabkan kelebihan maupun kekurangan nutrisi pada anak. Selain itu kebiasaan balita yang suka jajan dengan kandungan energi dan lemak yang cukup tinggi. Hal itulah yang menyebabkan terjadinya penumpukan penyimpanan lemak di dalam tubuh balita (Wulandari et al, 2015). Penelitian lain yang dilakukan oleh Kusumaningrum \& Sudikno (2012) menyebutkan bahwa anak yang mengkonsumsi tinggi protein akan cepat memicu terjadinya kegemukan, karena kelebihan asupan protein akan disimpan dalam bentuk lemak yang menjadi faktor kegemukan pada balita. Oleh karena itu untuk menjaga berat badan balita dalam masa pertumbuhan sebaiknya mengatur pola asupan lemak dan protein pada tubuh balita.

\section{KESIMPULAN}

Berdasarkan hasil penelitian menunjukkan bahwa Indeks Masa Tubuh, pemberian Makanan Pendamping ASI dini dan pola asupan nutrisi berhubungan dengan kejadian overweight pada balita usia 35 tahun dengan nilai $\mathrm{p}<0,05$. Diharapkan tenaga kesehatan dapat memberikan pengetahuan dan motivasi kepada orang tua untuk memberikan nutrisi yang sesuai dengan umur untuk mengurangi risiko kejadian overweight pada balita.

\section{REFERENSI}

Depkes RI. (2017). Bayi Gendut, Lucu Tapi Belum Tentu Sehat. http://www.depkes.go.id/pdf.php?id=17012300002. Diakses : Tanggal 20 Juni 2019.

Kementrian Kesehatan RI. (2012). Pedoman Pencegahan dan Penanggulangan Kegemukan dan Obesitas Pada Anak Sekolah. Jakarta : Kemenkes RI. (2014).Situasi dan Analisis ASI Akslusif. file http://www.depkes.go.id/download.php?file=download/pusdatin/infodatin/infodatin-asi.pdf. Diakses : Tanggal 28 Juli 2019. (2018). Hasil Utama Riskesdas 2018. Jakarta: Kemenkes RI.

Kusumaningrum, F., \& Sudikno. (2012). Faktor - Faktor Yang Berhubungan Dengan kegemukan Pada Anak Balita 24-509 Bulan di Indonesia Tahun 2010. Gizi Indonesia 2012, 35(1), 41-56.

Mariam, D., A., \& Larasati, T., A. (2016). Obesitas dan Peranan Orang Tua. Majority.5 (5).161-165.

Swanton, S., Choh, A., C., Lee, M., Laubach, L., L., Linderman, J., K., Czerwinski, S., A., \& Peterson, M., J. (2017). Body mass index associations between mother and offspring from birth to age 18: the Fels Longitudinal Study. Obesity science \& practice, $3(2), 127-133$.

Utami, C., T., \& Wijayanti, H., S. (2017). Konsumsi Susu Formula Sebagai Faktor Risiko Kegemukan Pada Balita di Kota Semarang. Journal of Nutrition College, 6(1), 96-102.

World Health Organization. (2018). Obesity dan Overweight. https://www.who.int/news-room/factsheets/detail/obesity-and-overweight. Diakses : Tanggal 20 Mei 2019.

Wulandari, N., Muniroh, L., \& Nindya, T., S. (2015). Asupan Energi dan Aktivitas Fisik Berhubungan dengan ZScore Anak Usia Sekolah Dasar di Pedesaan. Media Gizi Indonesia, 10, 51-56. 